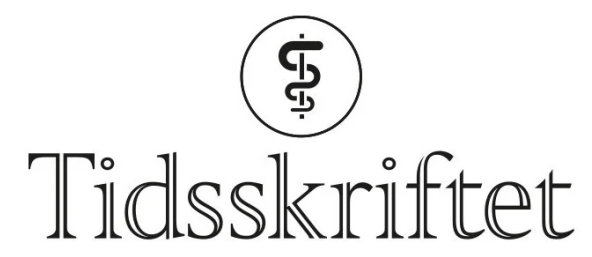

DEN NORSKE LEGEFORENING

\title{
Vanlige folks helsetjeneste
}

FRA REDAKTØREN

\section{ARE BREAN}

are.brean@tidsskriftet.no

Are Brean er sjefredaktør i Tidsskriftet. Han er ph.d. og spesialist i nevrologi.

\section{Hurdal-plattformen gir grunnlag for en styrket offentlig} helsetjeneste. Men lovnadene er mange og til dels vage. Hvor godt vil de stå seg i møte med hverdagspolitikken og stortingsflertallet?

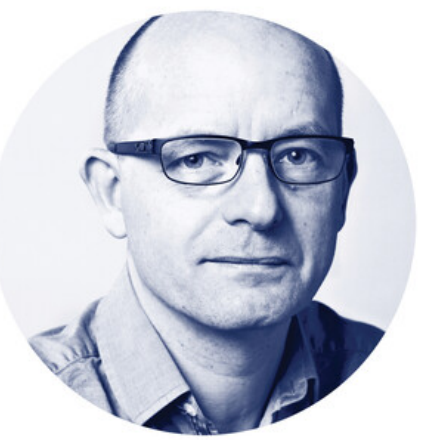

Foto: Einar Nilsen

13. oktober 2021 la Arbeiderpartiet og Senterpartiet frem sin regjeringsplattform, dokumentet som danner grunnlaget for politikken på sentrale områder de neste fire årene (1). Støre-regjeringen er opptatt av å være opptatt av «vanlige folk». Og vanlige folk er opptatt av helse. Da er det kanskje ikke så rart at helse har fått en prominent plass som ett av åtte hovedpunkter i plattformen.

Allerede på side 2 (etter at «vanlige folk» er nevnt seks ganger så langt) slås det fast at «vi vil ha en offentlig helse- og omsorgstjeneste i verdensklasse». Det er en god ambisjon. Men den døren står allerede åpen etter forrige regjering. I august 2021, åtte år inn i Erna Solbergs regjeringstid, kåret The Commonwealth Fund det norske helsevesenet til verdens beste (2).

Selv verdens beste helsetjeneste har sine åpenbare utfordringer. Støre-regjeringens svar på disse er enkelte helt konkrete kursendringer, noen flere utydelige lovnader og ganske mange "utredninger».

Som et sammenslått ekko av de to partienes programmer slår regjeringsplattformen fast at en sterk offentlig helsetjeneste er avgjørende i «kampen mot økte sosiale (les: Ap) og geografiske (les: Sp) forskjeller og mot en todeling av helsetjenesten». Flere av de varslede 
kursendringene viser at regjeringen tar sin egen formulering på alvor. Det gjelder ikke minst for spesialisthelsetjenesten. Godkjenningsordningen i Fritt behandlingsvalg skal avvikles. Denne lite brukte ordningen har vært en fanesak for Høyre å opprettholde - og en fanesak for Arbeiderpartiet å avvikle. Det er også andre tydelige dreininger i den kommende helsepolitikken: Grunnfinansieringen til sykehusene skal økes, bruken av innsatsstyrt finansiering skal minskes, intensivkapasiteten på sykehusene skal økes, ordningen med nøytral merverdiavgift i helseforetakene skal avvikles og mål- og resultatstyringen skal reduseres. Og staten skal, etter hvert, overta ansvaret for luftambulansen. Psykisk helse er, som forventet, et tydelig satsningsområde. Det varsles en egen opptrappingsplan for både første- og annenlinjetjenesten, med særlig vekt på barneog ungdomspsykiatri og gratis psykisk helsehjelp for alle til og med fylte 25 år. Barselomsorgen får endelig en ny stortingsmelding, men pussig nok uten at svangerskapsomsorgen nevnes.

Langt ifra alle av den forrige regjeringens beslutninger skal reverseres. Til stor skuffelse for mange gjøres det ikke om på beslutningen om å legge ned Ullevål sykehus. Senterpartiet har gått høyt ut i valgkampen for å stoppe nedleggelsen. Det er derfor litt av en godbit Støre må ha gitt Vedum i forhandlingene i bytte mot dette sykehuset. I Kristiansund, derimot, gis det medhold til lokal sykehuskamp: Der skal fødeavdelingen reddes, men bare «såfremt det er faglig og økonomisk forsvarlig». Tydeligheten i sykehuslokalisering strekker seg likevel ikke helt mot nord. I Alta skal man bare «følge opp prosessen for å videreutvikle spesialisthelsetjenester». Nytt sykehus nevnes ikke.

\section{«Helsevesenet er ikke et vesen man bør ncerme seg uten en viss ydmykhet for både kompleksiteten og for en rekke sterke faglige og fagpolitiske interessenter»}

En styrking av fastlegeordningen inngikk i begge partiers lovnader før valget. Det gjenspeiles i deres felles plattform. Regjeringen skal etablere nye rekrutteringshjemler, korte ned listelengden til fastlegene og $\varnothing$ ke basistilskuddet per innbygger. Det skal bli gratis å gå til fastlege til og med fylte 18 år. Ellers er avsnittet om primærhelsetjenesten forbausende vagt. Man skal «vurdere», «sikre», «utrede» og «arbeide for» flere gode saker men betydelig færre enn for sykehusenes del.

Blant de mer utydelige lovnadene er en ny nasjonal kreftplan med «ambisjoner om å desentralisere deler av kreftbehandlingen». Likeså ullen er effekten av en ny «helsepersonellkommisjon» som skal «fremme tiltak for å utdanne, rekruttere og beholde kvalifisert helsepersonell over hele landet». I dette ligger det ingen forpliktelse til å utdanne mer helsepersonell, bare at utdanningen skal spres over hele landet.

Og så var det alt som skal «utredes»: Maksimal reisetid til legevakt. Løsninger som hensyntar fastlegenes arbeidsbelastning. En tydeligere organisering og ledelse av rehabiliteringstilbudet. Modeller for samarbeid med ideelle drivere av luftambulanse. «Null-pluss»-alternativet for Innlandet sykehus. Og ikke minst endringer i helseforetaksmodellen. I tillegg kommer en rekke andre endringer som skal "vurderes». Alt dette kan høres svært vagt ut. Men akkurat det er nok både villet og klokt. For helsevesenet er ikke et vesen man bør nærme seg uten en viss ydmykhet for både kompleksiteten og for en rekke sterke faglige og fagpolitiske interessenter. Disse bør gis medansvar når betente saker skal avgjøres. Det gir man nettopp gjennom medvirkning i utvalg og utredninger.

Det er i det samme lyset man må se avsnittet om abortloven. Her skal det nemlig også utredes og settes ned utvalg som skal «se på» alternativer til dagens abortnemnder. Interessant nok fristiller plattformen de to partiene i abortspørsmålet, og de står «fritt til å søke flertall i Stortinget for sine standpunkter». Slik forebygges en potensiell regjeringssplittelse. 
I de kommende ukene og månedene skal Hurdal-plattformen få bryne seg på både et storting der regjeringen ikke har flertall, og på økonomiske hverdagspolitiske begrensninger. Helsedelen av plattformen er et godt utgangspunkt for en styrket offentlig helsetjeneste. Men den er også full av lovnader om mer ressurser og mer penger til det aller meste innen helse og omsorg - samtidig som regjeringen lover å ikke øke det samlede skatte- og avgiftstrykket. Det blir interessant å se hvor godt helselovnadene vil stå seg $\mathrm{i}$ kampen med alle andre viktige saker for vanlige folk.

\section{LITTERATUR}

1. Hurdalsplattformen for en regjering utgått fra Arbeiderpartiet og Senterpartiet 2021-2025. https://res.cloudinary.com/arbeiderpartiet/image/upload/v1/ievv_filestore/43boda86f86a4e4bb1a861 gfizdegdagafe348b29bf24fc8a319edgbo2dd284e Lest 13.10.2021.

2. Schneider EC, Shah A, Doty MM et al. Mirror, mirror 2021: Reflecting poorly. Health care in the U.S. compared to other high-income countries. New York, NY: The Commonwealth Fund, 2021. https://www.commonwealthfund.org/publications/fund-reports/2021/aug/mirror-mirror-2021reflecting-poorly Lest $13 \cdot 10.2021$.

Publisert: 14. oktober 2021. Tidsskr Nor Legeforen. DOI: 10.4045/tidsskr.21.0725

(C) Tidsskrift for Den norske legeforening 2023. Lastet ned fra tidsskriftet.no 26. april 2023. 